University of Wollongong

Research Online

Faculty of Education - Papers (Archive)

Faculty of Arts, Social Sciences \& Humanities

$1-1-2012$

\title{
Transformations and self discovery: Stories of women returning to
} education

Cathy Stone

Open Universities Australia, copaconnect63@gmail.com

Sarah O'Shea

University of Wollongong, sarah.oshea@curtin.edu.au

Follow this and additional works at: https://ro.uow.edu.au/edupapers

Part of the Education Commons

\section{Recommended Citation}

Stone, Cathy and O'Shea, Sarah: Transformations and self discovery: Stories of women returning to education 2012.

https://ro.uow.edu.au/edupapers/377

Research Online is the open access institutional repository for the University of Wollongong. For further information contact the UOW Library: research-pubs@uow.edu.au 
O'Shea, S. \& Stone, C. (2011). Transformations and self-discovery: mature-age women's reflections on returning to university study.. Studies in Continuing Education, 33 (3), 273288.

Link to publisher version: http://sarahoshea.cgpublisher.com/ 